\title{
Analysis of the Frequency of Academic Staff and Students`Use of Information and Communication Technology (ICT) in Katsina State College of Education
}

\author{
Mbaba, A. E., Shema, I. M. \\ Isa Kaita College of Education Dutsin-Ma, Katsina State, Nigeria
}

\begin{abstract}
The paper analyze the frequency of academic staff and students use of information and communication technology \{Ict\} in Katsina State College of Education, it explore the ability of staff and students in computer application 114 academic staff and 1995 students were engaged in the study. A survey research design was used; the data collected was analyzed using percentage to present the responses. 4 point Likert-scale was used, while a mean of 2.50 was adopted to determine the higher and lower participation in the use of ICT and ability in computer application. The finding show that the use of ICT in the College is high $[\mathrm{m}=2.78$ higher than $\mathrm{m}=2.50]$. The study also indicated that the academic staff are more competent in the use of wide range of computer applications than students are [ $\mathrm{m}=3.08 \mathrm{and} 2.56$ respectively] the study reveals that the staff and students actually engaged in the use of ICT almost on a daily basis for both school learning and individual use. The researchers therefore recommend that this study should be carried out in all the tertiary institutions in Nigeria to clarify the uncertainty of the frequency of ICT use in Nigeria schools.
\end{abstract}

Keywords: Information, Communication, Technology, Frequency, Competency

\section{Introduction}

There is a growing trend towards the adoption of electronic learning as a frame work for enhancing quality delivery of education is the quest to achieve educational development. This effort result to the integration of information and communication technology (ICT) in education. According to Udie and Ekpang in Babalola et al., (2008) the use of ICT has created opportunity for collaborative learning among group of students, in which students take responsibility for their own learning and which students work with others on complex, extended real world-like problem. UNESCO (2003) stipulated that ICT constitutes new tools in the hands of teachers. Teachers are key forces in tapping ICT facilitated learning opportunities. yet many lack the knowledge, skills and attitudes to effectively use ICT as tools to enhance learning Farell and Wachelz (2003) affirm that the limited use of technology for teaching was not only due to lack of facilities but also due to teachers knowledge skills, beliefs and expertise, teachers need more training not only in computer literacy but also coherent strategies are needed to enable teachers fully integrate ICT as pedagogical tools even in the classroom. Inspite of the integration of ICT in teaching and learning and the exclusive inclusive of these (ICT) technology into educational activities run by schools across the world national center for educational statistics (2000) affirm that there is dramatic growth in the availability of technology in schools, there is still a great deal of evidence that teachers do not use technology as expected. In Nigeria, the governments have invested a lot to support the integration of ICT in teaching and learning in the schools. However, what is still lacking is adequate monitoring and evaluation of such government investment. Keengwe (2007) is of the opinion that investment in ICT should be followed with continues evaluation in terms of how such technology is used. Technology is important, but what is more important is how it can be used to enhance the quality of teaching and learning expected.

The integration of ICT in education is to ensure effectiveness and efficiency in teaching and learning. ICT is an increasingly powerful means to enhance one ability to think, to learn, to communicate and to use ones brain creatively and logically, however, a number of challenges has been observed to be responsible for the failure of the scheme, accordion to Federal Ministry of Education (FME) 2001 cited in Badamasi (2010) Nigeria is experiencing a severe shortage of ICT skills and personnel necessary for taking advantage of the new Emerging technologies in the knowledge society. More so, there is a growing uncertainty of academic staff and student's ability and competency in the use of ICT in Nigeria tertiary institutions inspite of its availability in the schools. 
This study is design to examine the frequency of academic staff and students participation in the use of ICT in Katsina state College of Education Nigeria, because the facilities are available to some extent but how well the facilities are use becomes the focus of the study. The study will also determine the ability of academic staff and students in computer appreciation. Finally, the study will explore and relate the ability of the both groups under study to be able to identify the group with a high ability in computer applications. Specifically, this study attempts to answer the following research questions:

- How often do academic staff and students use ICT?

- What type of computer applications are academic staff and students able to use?

- Are there any differences in academic staff and students' ability in computer appreciation?

\section{Research Design and Procedure}

A survey research design was employed for the study. The population is made up of 216 academic staff from the 5 schools (education, art and social science, science, languages and vocational and technical education) of the college and 4583 students across NCE 1 and NCE 3 of the college. In all 120 academic staff across the five schools and 2100, students across the three levels within the five schools were sampled for the study. The mode of sampling is what Nworgu (1995) calls "purposive or judgemental sampling". Purposive or judgmental sampling involves the use of specific elements, which satisfy some predetermined criteria (Nwikina, 2010). Hence, the representativeness of such samples was assumed in this study.

Instrument for data Collection: The instrument for data collection was a structured questionnaire developed by the researcher. It was validated by experts from the department of educational foundation of the college. A4 point Likert -type scale was adopted for the option and used for the study. the options are :almost every day $(A)=4$, A few times each week $(B)=3$, a few time each month $(C)=2$, and never $(D)=1$, for items in research question 1, while the options for research questions 2 and 3 are:- I do this myself $(A)=4$, I seek assistance of someone when doing this $(B)=3$, I have knowledge of this but can't do it (C)=2, I can start this but can't get what I went (D)=1.

Method of data Collection: The instrument used was a questionnaire administered to 120 academic staff and 2100 students within the college. It took a week to administer the questionnaire to the staff as the researcher move from office to office; the collection was also in same manner. While the students' questionnaire was given to them at their lecture venues and was retrieved immediately it was completed. However, not all the questionnaires could be retrieved. A total of 2109 questionnaires were returned out of which academic staff returned 114 out of the sampled 120 and 1995 students questionnaire was also collected back out of 2100 students that was sampled. This 2109 questionnaire collected was used for data analysis.

\section{Results}

Research Question 1: How often do academic staff and students use ICT?

The below findings revealed that ICT has gained ground in Katsina State College of Education inspite of the fact that it was not a long time since it was introduced and the facilities provided. Going by the mean of frequency of usage ( $\mathrm{m}=2.78$ higher than 2.50) the use ICT among staff and students has been impressive. The activities that staff and students usually do almost every day are using reference and research tools on the internet to install in computer such as electronic encyclopaedia, atlases, Bible, Qur'an etc $(\mathrm{m}=3.72)$, surfing the internet to lookup information about people, places, things or ideas and to catch the latest news $(\mathrm{m}=3.83)$,using the internet for sending and reviewing documents, messages through email $(\mathrm{m}=3.35)$, using the internet to download learning/research materials such as articles and journals $(m=3.11)$, using the internet to download software like educational software as well as multimedia items such as music and videos $(\mathrm{m}=2.83)$, GSM phones to make and receive call etc. $(\mathrm{m}=4.0)$, computer for word processing MS Word $(\mathrm{m}=2.53)$ and any computer based instructional software for teaching $(\mathrm{m}=2.92)$. The activities that are less frequently practiced (i.e. a few time each month or never) are computer games and simulation for teaching and learning $(\mathrm{m}=1.96)$, using the computer to create and use presentation packages e.g. MS-power points 
$(m=1.07)$ and spreadsheet software such as MS Excel or Lotus to develop a budget, statistics, organize C.A, and calculate CGPA or analyze scientific data $(\mathrm{m}=1.90)$.

Table 1: Academic staff and students' frequency of ICT use

\begin{tabular}{|c|c|c|c|c|c|c|}
\hline \multirow[t]{2}{*}{$\mathbf{S} / \mathbf{N}$} & \multirow[t]{2}{*}{ ICT FREQUENCY OF USE } & \multicolumn{4}{|c|}{ Valid Percent } & \multirow[t]{2}{*}{$\mathbf{M}$} \\
\hline & & 4 & 3 & 2 & 1 & \\
\hline 1. & Computer for word processing (i.e. MS word) & 16.22 & 40.11 & 24.23 & 19.44 & 2.53 \\
\hline 2. & $\begin{array}{l}\text { Spreadsheet to software (such as ms excel or lotus } \\
\text { develop budget, statistics, organize C.A and calculate } \\
\text { C.G.P.A or analyze scientific data) }\end{array}$ & 4.03 & 17.92 & 43.30 & 35.75 & 1.90 \\
\hline 3. & $\begin{array}{l}\text { Computer to create and use presentation packages e.g. } \\
\text { ms-power points. }\end{array}$ & 0.38 & 1.42 & 2.94 & 95.26 & 1.07 \\
\hline 4. & $\begin{array}{l}\text { Any computer based instructional software or } \\
\text { courseware for teaching and learning. }\end{array}$ & 20.44 & 29.02 & 12.32 & 38.22 & 2.32 \\
\hline 5. & $\begin{array}{l}\text { Reference and research tools on the internet or } \\
\text { installed in computer such as electronic encyclopaedia } \\
\text { atlas, Qur'an, bible etc. }\end{array}$ & 86.30 & 3.79 & 5.64 & 4.27 & 3.72 \\
\hline 6. & $\begin{array}{l}\text { The internet to lookup information about people, } \\
\text { places, things or ideas and to catch the latest news. }\end{array}$ & 90.66 & 3.32 & 4.65 & 1.37 & 3.83 \\
\hline 7. & $\begin{array}{l}\text { The internet for sending and receiving documents, } \\
\text { messages, through email. }\end{array}$ & 66.95 & 15.17 & 3.85 & 14.03 & 3.35 \\
\hline 8. & $\begin{array}{l}\text { The internet to download leaning/research materials } \\
\text { such as articles and journals. }\end{array}$ & 49.26 & 19.49 & 23.76 & 7.49 & 3.11 \\
\hline 9. & $\begin{array}{l}\text { The internet to download soft ware like educational } \\
\text { software as well as multimedia items such as music } \\
\text { and videos. }\end{array}$ & 42.30 & 17.92 & 20.06 & 19.72 & 2.83 \\
\hline 10 & $\begin{array}{l}\text { GSM phones to make and receive calls, send text } \\
\text { message, conference cell etc. }\end{array}$ & 100 & - & - & - & 4.0 \\
\hline 11 & $\begin{array}{l}\text { Computer games and simulations for teaching and } \\
\text { learning. }\end{array}$ & 6.31 & 31.86 & 13.80 & 48.03 & 1.96 \\
\hline
\end{tabular}

Mean of Frequency of use $=2.78$

Response Scale: 4 =almost every day, 3 =a few times each week, $2=$ a few times each month, $1=$ never

Research Question 2 and 3

- What type of computer application are staff and students able to use?

- Are there any differences in academic staff and student's ability in computer appreciation?

Table 2: Staff ICT Ability

\begin{tabular}{llcccccc}
\hline $\begin{array}{l}\text { Types of Computer Applications used by } \\
\text { staff }\end{array}$ & \multicolumn{3}{c}{ Valid Percentages (\%) } & & Mean & Remarks \\
\hline & & 4 & 3 & 2 & 1 & & \\
1 & Surf the internet & 71.93 & 12.28 & 8.77 & 7.02 & 3.49 & Good \\
2 & Copy a file from a flash drive/CD-ROM & 13.16 & 13.163 & 22.81 & 50.89 & 1.89 & Poor \\
3 & Scroll up and down a document & 100 & & & & 4.0 & Good \\
4 & Create/ edit a document & 69.30 & 21.93 & 1.75 & 7.02 & 3.54 & Good \\
5 & Open a file & 64.91 & 21.93 & 7.02 & 6.14 & 3.46 & Good \\
6 & Install, update and scan the computer for & 14.04 & 22.81 & 21.05 & 42.10 & 2.08 & Poor \\
& virus. & & & & & & \\
7 & Save a computer document or file. & 67.54 & 19.30 & 7.89 & 5.27 & 3.49 & Good \\
& & & & & & \\
\hline
\end{tabular}




\begin{tabular}{|c|c|c|c|c|c|c|c|}
\hline 8 & Print a computer document or file. & 75.44 & 12.28 & 3.51 & 8.77 & 3.54 & Good \\
\hline 9 & Delete a document or file & 85.96 & 1.75 & 9.65 & 2.63 & 3.71 & Good \\
\hline 10 & Copy or download files from the internet & 28.42 & 10.53 & 8.77 & 7.89 & 3.48 & Good \\
\hline 11 & Attach a file on an email & 74.56 & 12.29 & 7.89 & 5.26 & 3.56 & Good \\
\hline 12 & Create a computer graphic (e.g. logo) & 10.53 & 5.26 & 8.77 & 75.44 & 1.51 & Poor \\
\hline 13 & Create a presentation using power point & 5.26 & 12.28 & 50.88 & 31.58 & 1.91 & Poor \\
\hline 14 & Start and play computer game & 54.39 & 23.68 & 15.79 & 6.14 & 3.26 & Good \\
\hline 15 & $\begin{array}{l}\text { Download music/videos and pictures } \\
\text { from the internet. }\end{array}$ & 64.04 & 15.78 & 10.53 & 9.65 & 3.34 & Good \\
\hline
\end{tabular}

Academic staff ICT ability mean $=3: 08$

Response scale: (4)= I do this myself, (3)=I seek assistance of someone when doing this, (2)=I have knowledge of this but can't do it, (1) I can start this but can't get what I want.

The findings, as shown in table 2 have shown that most academic staff have the ability to operate a wide range of the computer applications $(\mathrm{m}=3.08)$, surf the internet $(\mathrm{m}=3.49)$, scroll up and down a document $(\mathrm{m}=40)$, create/edit a document $(\mathrm{m}=3.54)$, open a file $(\mathrm{m}=3.46)$, save a computer document or file $(m=3.49)$, print a computer document or file $(m=3.54)$, delete a document or file $(m=3.71)$, copy or download files from the internet $(\mathrm{m}=3.48)$, attach a file to an email $(\mathrm{m}=3.56)$, start and play a computer games $(m=3.26)$, download music, videos, pictures from the internet $(m=3.34)$. However, the ability of academic staff is poor in some of these computer applications e.g. copy a file from flash drive $(\mathrm{m}=1.89)$, create a computer graphic e.g. logo $(\mathrm{m}=1.51)$, create a presentation using power point $(\mathrm{m}=1.91)$ and install, update and scan the computer for virus $(\mathrm{m}=2.08)$. These four applications require the staff to undergo more training especially in advance computer skills in order to improve.

\section{Table 3: Students ICT ability}

\begin{tabular}{|c|c|c|c|c|c|c|c|}
\hline \multirow[t]{2}{*}{$\mathbf{S} / \mathbf{n}$} & \multirow[t]{2}{*}{ Students items } & \multicolumn{4}{|c|}{ Valid Percentages (\%) } & \multirow[t]{2}{*}{ Mean } & \multirow[t]{2}{*}{ Remark } \\
\hline & & 4 & 3 & 2 & 1 & & \\
\hline 1. & Surf the internet & 60.45 & 20.25 & 16.59 & 2.71 & 3.38 & Good \\
\hline 2. & Copy a file from a flash drive & 35.69 & 10.18 & 15.19 & 38.94 & 2.43 & Poor \\
\hline 3. & Scroll up and down a document & 70.93 & 17.69 & 9.02 & 2.36 & 3.57 & Good \\
\hline 4. & Create/edit a document & 21.25 & 24.71 & 28.97 & 25.07 & 2.42 & Poor \\
\hline 5. & Open a file & 52.93 & 15.24 & 15.09 & 16.74 & 3.44 & \\
\hline 6. & $\begin{array}{l}\text { Install, update and scan the computer } \\
\text { for virus }\end{array}$ & 11.83 & 1.60 & 75.24 & 11.33 & 2.14 & Poor \\
\hline 7. & Save a computer document or file & 40.25 & 41.70 & 6.12 & 11.93 & 3.10 & Good \\
\hline 8. & Print a computer document or file & 52.28 & 30.28 & 10.63 & 6.81 & 3.28 & Good \\
\hline 9. & Delete computer document or file & 50.23 & 20.20 & 15.14 & 14.43 & 3.06 & Good \\
\hline 10. & Copy or download file from the internet & 2.11 & 75.09 & 20.15 & 2.65 & 2.77 & Good \\
\hline 11. & Attach a file on an email & 5.11 & 4.92 & 80.30 & 9.67 & 2.05 & Poor \\
\hline 12. & Create a computer graphic (e.g. logo) & 1.41 & 4.51 & 8.47 & 85.61 & 1.22 & Poor \\
\hline 13. & $\begin{array}{l}\text { Create a presentation (using power } \\
\text { print) }\end{array}$ & 1.75 & 0.40 & 96.84 & 1.01 & 2.03 & Poor \\
\hline 14. & Start and play a computer game & 75.24 & 10.28 & 9.37 & 5.11 & 3.56 & Good \\
\hline 15. & $\begin{array}{l}\text { Download music/videos and pictures } \\
\text { from the internet }\end{array}$ & 15.14 & 70.63 & 5.76 & 8.47 & 2.92 & Good \\
\hline
\end{tabular}

Mean of Students ICT Ability $=2.56$

The data in Table 3 above indicates that the students' ability in computer appreciation is good ( $\mathrm{m}=2.56$, higher than 2.50). The activities students do better include: surfing the internet $(\mathrm{m}=3.38)$, scrolling up and down a document $(\mathrm{m}=3.57)$, opening a file $(\mathrm{m}=3.44)$, saving a computer document or file $(\mathrm{m}=3.10)$, printing computer document or file $(\mathrm{m}=3.28)$, deleting computer document or file $(\mathrm{m}=3.06)$, copying or downloading 
a document or file from the internet $(\mathrm{m}=2.77)$, starting and playing a computer game $(\mathrm{m}=3.56)$, downloading music, videos and pictures from the internet $(\mathrm{m}=2.92)$. While the applications with poor abilities include copying a file from a flash drive $(\mathrm{m}=2.43)$, creating and editing a document $(\mathrm{m}=2.42)$, installing, updating and scanning the computer for viruses $(\mathrm{m}=2.14)$, creating a computer graphic e.g. $\log (\mathrm{m}=1.22)$, creating a presentation using power point $(\mathrm{m}=2.03)$, and attaching a file to an email $(\mathrm{m}=2.05)$. These applications have challenges because the students need training and retraining to be able to use all these applications effectively.

Discussion: The findings of this work reveals that staff and students of the college are using ICT on a frequent basis $(\mathrm{m}=2.78$ higher than 2.50$)$ as shown in table 1 , though there are challenges especially in the use of spreadsheet software $(\mathrm{m}=1.90)$, creating and using presentation packages such as Power point $(\mathrm{m}=1.07)$, computer games and simulation for teaching and learning $(\mathrm{m}=1.96)$. Table $2 \& 3$ shows that the staff ability in computer application is high $(\mathrm{m}=3.08)$ and students ability is rated high $(\mathrm{m}=2.56)$, using the adopted mean of 2.50. There is great ability in computer appreciation in the college. The mean also shows that the staffs are of high ability in computers appreciation than students with means of 3.08 and 2.56 respectively.

\section{Educational Implications and Suggestions}

Technology has been integrated in the learning activities of the college but it is not clear, if it has yielded any impact in building of knowledge. Marwan (2008) suggested that the focus of ICT integration should be directed towards achieving the effective attainment of knowledge through technology. That is, teachers should be aware that efforts need to be made to ensure that teaching using ICT can provide better learning outcomes than that of the conventional teaching. This study indicates high ability in computer appreciation among staff than students. This could be trace to one basic fact that almost all the staff used in this study has computers of their own while on the part of the students a very large number depend on the school computers. This is a fact that also determines how fast students can improve on their abilities. Therefore, the introduction of a policy that will ensure that all students in all the tertiary institutions own computers should be encouraged. Finally, the researcher recommends that similar study should be carried out in other tertiary institutions across the nation; this will show the frequency with which ICT has been integrated in our school system in Nigeria.

\section{References}

Babalola, J. B., Akpa, G. O. \& Imam, H. (2008). Managing Education for Sustainable Development in Developing Countries. NAEAP, Mokola Ibadan.

Badamasi, J. (2010). Re Invigorating Information and Communication Technology (ICT) for a visionary Nigeria. Isa Kaita Multidisciplinary Journal of Education, 4(1).

Farell, G. \& wachol, Z. (2003). Meta survey on the use of Technologies in Education in Asia and the pacific in: visiada C. Zembulas M; \& Legaspi, J.M.B empower ICT: e-learning for in Service Teacher Education and Supports.

Keengwe, J. (2007). Faculty Integration of Technology in to Instruction and students perceptions of Computer Technology to improve students' learning. Journal of information technology education, 6, 169-180.

Marwan, A. (2008). An analysis of Australian student's use of information and communication technology (ICT) available at www.itdl.org/article05.ltm

National centre of educational statistics. (2000). Teachers tools for the $21^{\text {st }}$ century. Reports on teacher's use of technology in Usida; c. Zembulas. M \& legasp PMB empower ICT; e-learning for In-service teachers' education and support. International journal of computer the internet and management, 12, 281-86.

Nwikina, L. (2010). University of Lagos communities level of satisfactions with the self-reliance measure at the institutions. Nigerian Journal of Curriculum Theories \& Educational Technologist, 1(1).

Nworgu, B. G. (1995). Educational Research: basic issues and Methodology, Ibadan: wisdom publishers limited.

UNESCO. (2003). Mapping Globalization: Selected Cross-cutting issues: role of ICT in bridging the digital divide in selected area. Economic and Social Commission for Asia and the pacific. 